\title{
Community Groups Cares for Aids for Optimization of High-Risk Population Outreach in Regions Pried io HIV/AIDS Transmission
}

\author{
Arulita Ika Fibriana ${ }^{1}$, Bambang Budi Raharjo ${ }^{2}$, Muhammad Azinar ${ }^{3}$ \\ \{arulita.ika.f@mail.unnes.ac.id ${ }^{1}$, bambangbr@mail.unnes.ac.id², azinar.ikm@mail.unnes.ac.id ${ }^{3}$ \} \\ Universitas Negeri Semarang, Semarang, Indonesia ${ }^{1,2,3}$
}

\begin{abstract}
Based on preliminary observations and the results of a situation analysis in Tanjung Mas, Semarang city, the problems are: 1) the last 6 years the highest HIV/AIDS cases in Semarang, 2) the population at high risk is increasing 3) public knowledge is still low, 4) outreach and information services have not been optimal for high-risk populations. AIDS Concern Community Groups really need to be formed at the village level. This research is a type of pre-experiment research with one group pretest posttest design with a quantitative approach. The research subjects were first given a pretest, then the implementation of outreach and education for 4 months and then a posttest. Data were analyzed by Mc Nemar test. Training for community groups concerned with AIDS has succeeded in increasing the knowledge and participation of the AIDS Concerned Community Group in outreach to at-risk populations and in an effort to prevent HIV/AIDS transmission in the community.
\end{abstract}

Keywords: people care about AIDS, education, high-risk population.

\section{Introduction}

The number of HIV/AIDS cases in Indonesia from year to year is always increasing. In the last three years, HIV cases have continued to increase significantly. New HIV cases in 2015 were 30,935 cases. This case increased in 2016 to 41,250 cases, and in 2017 HIV cases reached 48,300 cases. Likewise new AIDS cases, in the last three years in general has also increased. In 2015 AIDS cases totaled 9,215 cases, in 2016 increased to 10,146 cases, and in 2017 it decreased to 9,280 cases (1).

HIV/AIDS cases in Central Java Province have also increased from year to year. Cumulatively from 1993 to June 2018 in Central Java there have been 23,603 cases, 1,672 of whom died from this disease. This fact has made Central Java province ranked fifth with the highest number of HIV / AIDS cases nationally (1).

The highest number of HIV/AIDS cases in Central Java occurred in the city of Semarang. Tanjung Mas Village, North Semarang District in the last 6 years was recorded as the region with the highest HIV/AIDS cases in the city of Semarang, namely 24 cases (2). The high number of HIV/AIDS cases in these areas is indicated because the area is a port area which is prone to transmission of the HIV virus through risky sexual behavior. The large number of nightly entertainment venues such as karaoke, dim stalls, and the presence of sexual workers peddling themselves on the streets around the port are factors that cause risky 
sexual behavior. This fact is what makes this region one of the HIV/AIDS red zone areas in the city of Semarang.

Most cases of HIV in this region occurred in the male group, but other facts also show that in this region, HIV cases were also found in a group of housewives who were likely infected by their husbands who had risky behaviors. The impact of an HIV positive mother is that it can transmit to her child (3). Housewives who have never had a risky relationship, do not know anything because they only do activities at home, but they are infected with HIV. It is possible that this happened because of infection from her husband who had engaged in risky sexual behavior.

Husbands with HIV can infect their wives through unprotected sex. The sexual behavior of men who alternate partners with risk groups such as female sex workers (FSW) will be able to infect their wives. This will worsen the condition of women, especially when they are infected with HIV/AIDS. This condition is very worrying because in an HIV positive family there is a very high risk of transmitting to their partners and transmitting to their children (4).

The results of preliminary observations by the service team show that in the area of Tanjung Mas village as one of the areas at risk of spreading HIV, there are no sources and information services for HIV/AIDS that are easily accessible to the public. People only get information about HIV/AIDS from Puskesmas officers when there is a referral of suspected HIV cases through VCT services at the Puskesmas. Based on these facts, it is necessary to continue to make preventive efforts by increasing public understanding through educational models and intensive persuasion communication based on community empowerment.

Therefore, the formation of AIDS Concerned Community Groups (KMPA) at the village level is needed, especially in areas prone to HIV/AIDS transmission. KMPA will increase outreach, communication, information and education about HIV/AIDS in high-risk populations, especially in areas prone to HIV/AIDS transmission. The provision of information and education can increase the knowledge and awareness of people who are vulnerable to HIV/AIDS transmission. KPMA will be a facilitator and peer educator in the community to increase the knowledge and attitudes of the community towards HIV/AIDS prevention.

\section{Method}

This research is a type of pre-experiment research with one group pretest posttest design with a quantitative approach. The data was collected by filling out a pre-test and post-test questionnaires. This research intervention began with the formation of a community group concerned with AIDS totaling 9 people, who were then given training in HIV/AIDS outreach and education. The educational materials provided were facts about STDs and HIV/AIDS and their prevention and control in high-risk populations, awareness and motivation of the importance of preventing HIV/AIDS transmission.

Furthermore, the community group concerned with AIDS carried out outreach and education practices to the surrounding community and conducted education about HIV/AIDS for 4 months. The results of education carried out by community groups concerned with AIDS to the surrounding community for 4 months were analyzed by comparing initial knowledge and final knowledge after the intervention by Mc Nemar test. 


\section{Result and Discussion}

The assessment of the results of the intervention in this study was assessed from knowledge of AIDS Concerned Community Groups and public knowledge of HIV/AIDS. The training conducted for AIDS Concerned Community Groups has been able to increase the knowledge of these groups. Based on the evaluation of the results of the pre-test and post-test, the knowledge of the AIDS Concerned Community Group has increased. This is indicated by the difference in knowledge scores between before and after training.

Table 1. Differences in Pre and Post Test Results for AIDS Concerned Community Groups

\begin{tabular}{clcccc}
\hline \multirow{2}{*}{ Number } & \multirow{2}{*}{ Participants } & Sex & Pre-Test Score & $\begin{array}{c}\text { Post-Test } \\
\text { Score }\end{array}$ & Difference \\
\hline 1 & P1 & Female & 47.5 & 67.5 & 20.0 \\
2 & P2 & Male & 40.0 & 70.0 & 30.0 \\
3 & P3 & Male & 40.0 & 82.5 & 42.5 \\
4 & P4 & Female & 67.5 & 82.5 & 15.0 \\
5 & P5 & Female & 57.5 & 87.5 & 30.0 \\
6 & P6 & Female & 62.5 & 82.5 & 20.0 \\
7 & P7 & Male & 72.5 & 95.0 & 22.5 \\
8 & P8 & Female & 50.0 & 77.5 & 27.5 \\
9 & P9 & Female & 65.0 & 80.0 & 15.0 \\
& Mean & & 55.83 & 80.55 & 17.11 \\
\hline
\end{tabular}

These results indicate that there is a significant difference between the knowledge before and after the training. After training the knowledge score increased significantly ( $\mathrm{p}$ value 0.044). The mean score before training was 55.83 and increased to 80.55 after being given training.

Meanwhile, based on the results of outreach and assessment carried out by the AIDS Concerned Community Group, it is generally known that the risk factors for HIV/AIDS in the area of Tanjungmas Village are risky behavior, especially from male groups, namely, among others, sexual behavior with multiple partners, tattoos, piercing and drug abuse. Jobs as truck drivers and crew, inter-island fishermen who often leave their families for a relatively long time are one of the determinants of risky behavior in men.

Through education that has been carried out by the AIDS Concern Community Group, the knowledge of some people about HIV/AIDS will be better. This is indicated by an increase in community knowledge reached between the beginning of program implementation and the end of program implementation. At the start of this program, through home visits conducted by the AIDS Concerned Community Groups, it was found that of the 40 houses visited, only 10 houses $(25.00 \%)$ had good knowledge of HIV/AIDS. After re-education by the AIDS Concerned Community Group, the number of houses whose respondents began to know a lot about HIV/AIDS, the number increased to 31 houses (77.5\%).

The following is an illustration of the comparison of public knowledge regarding HIV/AIDS between before and after outreach by AIDS Concerned Community Groups. 
Table 2. Comparison of public knowledge about HIV/AIDS between before and after outreach by AIDS Concerned Community Groups

\begin{tabular}{lccccc}
\hline \multirow{2}{*}{ Knowledge } & \multicolumn{3}{c}{ After } & \multirow{2}{*}{ p value } \\
\cline { 3 - 5 } Before & Not good & $8(20,0 \%)$ & $22(55,0)$ & $30(75,0 \%)$ & $<0,05$ \\
& Good & $1(2,5 \%)$ & $9(22,5 \%)$ & $10(25,0 \%)$ & \\
& amount & $9(22,5 \%)$ & $31(77,5 \%)$ & $40(100,0)$ & \\
\hline
\end{tabular}

Based on the Mc Nemar test, it is known that the $\mathrm{p}<0.05$. This shows that there is a significant increase in knowledge about HIV/AIDS in the community between before and after outreach by AIDS Concerned Community Groups. These results prove that the outreach and education about HIV/AIDS that has been carried out by the AIDS Concern Community Group in the Tanjungmas Village area has had an impact on increasing public knowledge about HIV/AIDS.

This increase in knowledge occurs because of the provision of information and in it there is a learning process. The learning process according is defined as a process to increase knowledge, understanding, and skills that can be obtained through experience or conducting studies. This study is in line with the results of research which states that the health education provided to the community has an effect on increasing knowledge and attitudes (6). Other research also states that there is an effect of health education on increasing knowledge and attitudes in controlling HIV/AIDS (5).

Other studies suggest that there is an effect of health education on increasing knowledge and attitudes in controlling HIV/AIDS (5). Mutual support or mutual support to realize the importance of efforts to prevent HIV/AIDS transmission between fellow FSW groups has influenced the better awareness of FSW in preventing HIV/AIDS transmission, namely by increasing condom use, increasing FSW participation in STI screening and participation in VCT. This result is also consistent who stated that group support can increase the perception of the benefits of prevention and the impact of sustainable HIV transmission (6). Prevention and peer-based care markedly reduced the incidence of HIV among young FSW in Burkina Faso, through a reduction in risky behavior (7).

Health education and promotion has an effect on increasing knowledge about HIV/AIDS (8). Health education can increase knowledge and attitudes in HIV/AIDS prevention (9). Educational programs on HIV/AIDS could increase public knowledge about HIV/AIDS (10).

Other research, which states that HIV/AIDS health education can have a significant effect on knowledge about the practice of disease-risk sexual behavior. Effective sexual health education becomes the responsibility of individuals to achieve sexual health. Therefore, everyone must have a correct understanding of sexual health including knowledge of HIV/AIDS, so that each individual can make ethical sexual health decisions (11). Health education has a positive influence on awareness of HIV/AIDS and increased knowledge of modes of transmission and prevention of HIV/AIDS (12). Knowledge is an important determinant for changing health behavior (13). 


\section{Conclusion}

The program to strengthen the role of community groups concerned with AIDS in the Tanjungmas sub-district, Semarang city, was carried out by forming a community group concerned with AIDS and training community groups concerned with AIDS as peer educators. Training for community groups concerned with AIDS has succeeded in increasing the knowledge and participation of AIDS Concerned Community Groups in outreach to at-risk populations as well as in efforts to prevent HIV/AIDS transmission in the community.

The community group concerned about AIDS is an active role of the community in the prevention and control of HIV/AIDS in the community. Therefore, this program can be adopted and implemented in all regions, especially in areas prone to HIV/AIDS transmission.

\section{References}

[1] Ministry of Health. (2018). Report on the Situation of the Development of HIV \& AIDS in Indonesia in 2018. Jakarta: Ministry of Health.

[2] AIDS Commission of Semarang. (2018). Report on HIV/AIDS Cases in Semarang City. Semarang: AIDS Commission of Semarang.

[3] Gondo, HK. (2008). Prevention of Mother-to-Baby Transmission of HIV. Surabaya : FK Universitas Wijaya Kusuma.

[4] Dalimoenthe. (2011). Embrace Women in the Grip of HIV/AIDS: A Study of Feminist Sociology of Housewives of Women. Jurnal Komunitas. 5 (1).

[5] Purnomo, K.I., M, Bhisma., \& Putu, S. (2013). Comparison of the Effect of Peer Education Methods and Lecture Methods on Knowledge and Attitudes of HIV/AIDS Control in Sports and Health Faculty Students. Jurnal Magister Kedokteran Keluarga Universitas Pendidikan Ganesha, $1(1), 49-56$.

[6] Bateganya, M., Amanyeiwe, U., Roxo, U., Dong, M. (2015). The Impact of Support Groups for People Living with HIV on Clinical Outcomes: a systematic review of the literature. J Acquir Immune Defic Syndr. 68(03), 368-374.

[7] Traore, T., Isidore \& et al. (2015). HIV prevention and care services for female sex workers: efficacy of a targeted community-based intervention in Burkina Faso. J Int AIDS Soc 18(1).

[8] Takainginan, Caecilia; Pesak, Ellen; Sumenge, Dionysius. (2016). The Effect of Health Promotion About HIV / AIDS on Adolescent Knowledge Levels. JIDAN (Jurnal Ilmiah Bidan). 4 (1).

[9] Dewi, Nur Setiawati. (2008). The Effect of Health Education on Changes in Knowledge and Attitudes in HIV / AIDS Prevention in Commercial Sex Workers. Media Ners. 2 (1).

[10] Sharma M. (2008). Impact of Educational Intervention on Knowledge Regarding HIV/AIDS among Adults. J Nepal Health Res Counc. 6 (2).

[11] Kimani GN. Kara ML. and Nyala ML. (2012). Students' Sexual Behaviour in the Context of HIV/Aids Education in Public Secondary Schools: A Case for Kangudo Division, Kenya. International Journal of Humanities and Social Science. 2 (23).

[12] Jung M, Arya M, Viswanath K. (2013). Effect of Media Use on HIV/AIDS-Related Knowledge and Condom Use in Sub-Saharan Africa. Media Use and HIV/AIDS Sub-Saharan Africa. 8 (7).

[13] Viswanath K, Ramanadhan S, Kontos EZ. (2007). Mass media. In: Galea S, (eds.). Macrosocial Determinants of Population Health. NY: Springer. p. 275-94. 